\title{
The Effectiveness of Experiential Learning in a Large Classroom: An Example of the Auction Market
}

\author{
Alina M Zapalska, Dallas Brozik \\ U.S. Coast Guard Academy, Marshall University
}

\begin{abstract}
The research work in this paper presents an experiential learning activity for a large classroom where students take roles of travel agents to learn how a travel agency functions in an auction market. Students are provided with an uncertain environment in which they make strategic decisions aimed at maximizing their agency's returns. Players are expected to make strategic decisions while experiencing how market structures and decisionmaking affect commerce within a simulated tourism and hospitality industry. Students are expected to interact with team players to compete against other students and to receive an appreciation of the pressures present in a competitive market. This auction market has been designed for a large classroom where students learn through experience and discovery in competitive business environment.
\end{abstract}

\section{Introduction}

College education has been criticized for relying heavily on passive modes of learning such as lectures that leave college students unchallenged and with limited advancement of critical thinking and problem-solving skills. This criticism has generated even greater concern for teaching courses that have a large number of students. To respond to those challenges, academic teaching has focused increased interest in using teaching techniques that actively involve students in experiential learning in and outside the classroom using multiple approaches and phases of learning [1]. Requiring students to be active learners through experiential activities and practice promotes the effectiveness of learning. An example of learning from experience can be demonstrated with the use of experiential learning with simulations and games where active learning is based on reflective practice that places students in situations where they must perform tasks in order to gain new experiences and skills. The goal is to let students experience and discover something new and encourage reflection about their experience which prepares students for global citizenship. This reflection helps students develop new skills and new ways of higher order of thinking [2].

According to Kolb and Kolb [3], meta-cognitive aspects of experiential learning are efficient techniques when simulations and games are used to promote experiential learning and development. The authors argued that experiential learning not only supports the development of social skills, work ethic, but it also provides practical expertise and a deeper understanding of subject matter. Experiential learning develops deeper understanding, the capacity for critical thinking, reflective judgment, application of knowledge in complex or unclear situations, and supports the advancement of abilities that allow students to effectively engage in problem-solving, critical thinking, and lifelong learning [4].

Cooper [5] developed an integrated learning guide for students' learning and provided examples of effective practice that supports experiential learning. Educational programs are responsible for educating a new generation of citizens who are competent in self-directed learning that can be accomplished through the power of experiential learning. Academic programs, and especially those with large number of students, must prepare their graduates to be contributing members and leaders of their local and global communities. This educational challenge requires that academic faculty develop teaching techniques that allow students to experience and apply their acquired knowledge through specifically designed learning spaces and applications to realworld problems. Embedding experiential education into programs increases student recruitment, retention and completion rates of undergraduate programs as understanding and interpretation of theory; beliefs, values, and practice becomes efficient and resourceful.

This paper contributes to the existing literature on pedagogical approaches that develop critical thinking, deep learning, and problem-solving skills. It argues that Kolb's model of experiential learning is the foundation around which pedagogical techniques should be developed. The use of games and simulations provides all necessary steps or phases that advance the development of required skills in an entrepreneurial and business environment. When students are placed in an uncertain environment such as a game or simulation, they will be expected to make strategic decisions and interact with team players to compete against other students. The games and simulations can be designed for a large classroom where students learn through experience and discovery in a competitive business environment become actively involved and are able to develop critical thinking, problem-solving and 
life-long learning skills [6]. The paper demonstrates effectiveness of experiential learning with the use of the Auction Game, particularly focusing on a largesize classroom.

\section{Literature Review}

The Experiential learning is a pedagogical method applied in higher education to enhance students' learning. It has been defined as a teaching strategy that provides concrete experiences to students to complement traditional teaching modes such as lectures to boost students' learning and understanding of content, ideas, and concepts. Numerous terms have been used to name the process of learning from experience. Dewey [7] was the first who discussed learning by doing. Wolfe and Byrne [8] were the first authors who used the term experienced-based learning and emphasized reflection on direct and concrete experience. The AACSB Task Force developed the term applied experiential learning, combining the learning from the real-world situation with the necessary condition of the application of concepts, ideas, and theories to the interactive setting.

Much of the research on experiential learning theory has focused on the concept of learning style using the Kolb Learning Style Inventory (KLSI) to assess individual learning styles. Experiential learning involves participation and critical reflection on that participation. Experiential learning is where the learner participates in an activity, reflects on the activity, and then applies the lessons learned in new situations. The concept of deep learning describes the developmental process of learning that fully integrates the four modes of the experiential learning cycle - experiencing, reflecting, thinking, and acting.

Experiential learning has developed a holistic philosophy of education based on the view that an individual's life experiences, education, and work play a central role in their learning process of acquiring new knowledge [11]. Experiential learning has been measured as a set of tools and techniques that provides students with a range of experiences and as a progression where learners convey their own knowledge, ideas, beliefs, and practices to their comprehension and interpretation of new concepts and information. Experiential learning theory is based on the essential belief that learning occurs when individual players are provided with experiential learning opportunities facilitate the identification, discovery, and exploitation through active and concrete experience of new concepts that lead to reflection upon their experiences.

Experiential learning theory was originally developed and promoted by Kolb [10]. His book Experiential Learning is the best-known presentation of the approach to reflective and experiential learning. The author involved four modes of learning into experiential learning that included concrete experience, reflective observation, abstract conceptualization, and active experimentation, arguing that students must become skilled at all four learning modes.

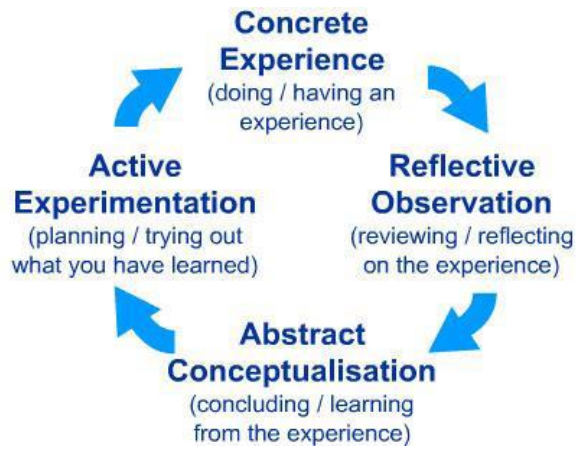

Figure 1. Kolb Learning Cycle Source: [20]

Figure 1 and Table 1 exemplify the four phases of Kolb's learning cycle to illustrate how learners experience learning from moving from one phase to the next.

Table 1. Kolb: Four Stages of Experiential Learning

Concrete Experience: This is the first step of the experiential learning process. Concrete Experience sees the learner involved in a new experience or situation. This also includes a reinterpretation of an existing experience.

Reflective Observation: The second step of Kolb's theory, reflective observation, involves systematic reflection on the new experience. This is an analytical step in which the learner consciously thinks about what they have just experienced. A particularly important aspect of this step is the realization of inconsistencies between experience and understanding.

Abstract Conceptualization: The learner delves deeper into their thinking about the subject. In this step, the learner constructs a new idea, or modifies an existing concept to explain their observations.

Active Experimentation: The final step of the process involves using these new theories to solve problems and make decisions. By applying their newly conceived understanding of the world around them, they are demonstrating their newfound knowledge. The process enters a new cycle when the learner uses this experimentation to create a new Concrete Experience.

Source: [10]

Kolb's framework specifically defines and allocates equal weight on all four parts of the learning cycle. 
This approach enables the efficient application of experiential learning in a course. Each learning mode is critical for students' learning, and students can begin experiential learning at any stage of this experiential learning cycle.

Supporters of Kolb's experiential learning cycle recommend application of various methods of learning that range from concrete, abstract, active, passive, primary, and secondary modes of learning (see Table 2) especially active learning through service learning, internships, field trips, and involvement in faculty research. Cohen [12] contend that learning will be effective if students are involved in a deep learning process where students learn from experience. The author supported the experiential learning cycle because it advances social skills, work ethic, practical expertise, and critical thinking. Application of knowledge through games and simulations using complex and uncertain situations will allow students to develop critical thinking and the ability to engage in lifelong learning. Field trips enable students to recall concepts learned and to reinforce learning through concrete experiences, reflective observation, and active experimentation.

Table 2. Modes of Learning and Their Characteristics

\begin{tabular}{|c|l|}
\hline $\begin{array}{c}\text { Modes of } \\
\text { Learning }\end{array}$ & \multicolumn{1}{|c|}{ Characteristics } \\
\hline Concrete & $\begin{array}{l}\text { The learning experience involves tangible } \\
\text { matters that may have real consequences } \\
\text { for the learner and/or others. }\end{array}$ \\
\hline Abstract & $\begin{array}{l}\text { The learning experience does not involve } \\
\text { real and tangible matters and has no } \\
\text { consequences beyond the learning. }\end{array}$ \\
\hline Active & $\begin{array}{l}\text { The learner actively participates in the } \\
\text { learning situation. }\end{array}$ \\
\hline Passive & $\begin{array}{l}\text { The learner adopts the role of observer } \\
\text { and/or listener when learning. }\end{array}$ \\
\hline Primary & $\begin{array}{l}\text { The learning situation is characterized by } \\
\text { immediacy and/or first-hand experience } \\
\text { with respect to the matter being learned. }\end{array}$ \\
\hline Secondary & $\begin{array}{l}\text { The learning situation is characterized by } \\
\text { mediacy and second-hand experience with } \\
\text { respect to the matter being learned. }\end{array}$ \\
\hline
\end{tabular}
Source: [21]

Some researchers recommended involving students in deep learning through active and cooperative learning and experimentation [13]. They also endorsed games and simulations for experiential learning. A variety of simulations and games ranging from simple to complex can be found for most classes in today's business and economics college curricula. This type of instruction provides students with an effective means of learning through experiences taken from actual situations into a controlled learning environment.

Research papers have been published that attempt to introduce experimental methods, an assessment of these available methods, and the usefulness of these methods to business education [14]. They also have strongly supported changing a lecture and adopting laboratory market experiments such as simulations and games and observed that group learning using simulations and games begins with concrete experiences and argued that by relying on reflective observations from these experiences, students engage in abstract conceptualization that allows them to generalize and learn principles that integrate their observations into working theories.

Simulations and games allow learners to actively experiment, test, and apply what they have learned in more complex situations. Simulations and games stimulated problem solving as well as reflective and critical thinking because players were required to make strategic decisions. According to Baker [15], the experiential-based activities eliminate memorization and repetition as well as provide opportunities for students to interact with each other. Students learn to question and try new approaches to explain their own ideas while learning.

The structure of a simulation or game is quite important. Games that seek to exercise a fundamental concept, like the free rider problem in economics, may be very simple in structure [16]. In this case, multiple repetitions of a simple game might be required to illustrate the principle. Other games that model complex operations, like the operation of a commercial bank, may have many aspects that must be mastered which required weeks to complete [17]. While both short- and long-term games have their applications, many instructors prefer games or experiments that take a single class period to illustrate a specific concept and to develop specific behavioral characteristics.

The single-period simulations and games have the advantage of being flexible in their applications as instructors can change plans according to the needs of the class and move the game to a different time without causing major disruptions in the class schedule. When a single-period game is properly designed, it becomes a valued tool for the instructor as it provides flexibility along with educational content. Zapalska and Brozik [4] have developed market simulations and games that can be adapted to a wide variety of situations ranging from simple barter to highly developed supply and demand driven economies.

The Joint Council on Economic Education has advocated modifying a lecture to enhance students' learning by using active laboratory market experiments. Simulations and games must be consciously constructed to have anticipated effects. In the Action Game students are provided with a learning instrument that is based on an experience where abstract conceptualization, active experimentation, concrete experience, and reflective 
observation are involved to create favorable learning environment.

The four Kolb's learning modes provide steps to structure the game so that learning from experience and reflection takes place. In this simulation, students are learning from concrete experience, actions, thinking, and reflection. Students are expected to develop strategies and actions. The postexperience stages that include reflection, debriefing, and discussion are used to reinforce their reflective observation and to confirm their abstract conceptualization. In addition, the simulation was structured for a large group of students.

Teaching large-size classes presents real challenges in design, management, and assessment. The academic faculty search for answers how to design teaching instruments that are effective and provide development of life-long learning skills in large-size classes [18]. Lund and Wright [19] argue that large-size classes have been understudied in the literature. The authors provided some guidelines to assist faculty with structuring experiential and active learning classroom exercises.

They recommended that faculty of large-size classes should engage in pre-class planning (significant preparation time must be allowed), proper use of course syllabus (the syllabus should help students understand the association between learning outcomes, in-class activities, and assessment requirements), plan on a page (preparation requires planning for content, process, and logistics), and keep it simple (the learning outcomes must be simple limited to the two or three critical items).

The authors also stated that in large-size classrooms in-class facilitation is important as verbal explanations might not work, and written instructions are necessary. Movement in a classroom is critical. In a traditional lecture hall, it can be very difficult to obtain dynamic movements of large groups. Debriefing is critical and might require the use of several instructors or graduate teaching assistants to help. The use of specially designed assignments and feedback allows students to move through the Kolb's learning cycle

\section{A Structural Taxonomy of Simulations and Games}

A "game" is structured to have a winner who can be the individual or a team that first successfully finishes the requirements of the game. The game provides a competitive setting for learning specific subject matter. In contrast, a "simulation" copies a portion of reality in a controlled setting and may replicate the social, economic, or political processes and interactions. Students assume active roles in the system and try to understand how the system operates. A simulation does not have a winner since its focus is on situational learning. A "simulation game" is a combination of the two techniques that uses the role-playing of a simulation for learning specific concepts and has a winner. The active and competitive nature of a simulation game can encourage students by providing a motivation for learning. Creating a "winner" inside the context of a simulation provides a motivating factor for the players to understand the environment and be successful.

\section{Abstract Conceptualization and Preliminary Steps}

\subsection{The Goal of the Game}

The Auction Game is a simulation that provides students with the experience of planning and implementing strategies in a competitive auction environment. The game is set so that abstract conceptualizations are created so that the players recognize concepts learned in a classroom. The players are informed that they work as travel agents within a twelve-agency tourism and hospitality industry.

Each agency has contracts with certain hotel groups and needs resources of groups contracted with other agencies. The activity includes an auction as travel agents bid for hotel rooms and offer their hotel rooms to be auctioned. Players make managerial decisions to experience market structures and strategic decision-making that affect commerce within a simulated tourism and hospitality industry. Students get hands-on experience that assists them in gaining an understanding of markets in all aspects of business. Students interact with team players to compete against other players and to receive an appreciation of the pressures facing travel agencies.

\subsection{Identify Available Resources}

The market segmentation is presented in the Master Auction Matrix (see Table 3) where rooms in some hotels will either be in shortage, equilibrium, or surplus. For example, there will be room shortages in Fairfield Inn, Holiday Inn Express and Holiday Inn. Room surplus will be present in La Quinta, Days Inn, Best Inn \& Suites, and Four Seasons Hotel. Hotels such as Inter-Continental, Radisson Hotels, Travelodge, and Crowne Plaza are all in equilibrium. In this game's set-up, players must go through abstract conceptualization where they must recall basic economic concepts they learned in class. Students will be required to discover that shortages, even demand, and surpluses situations are present.

The game begins by distributing an instruction sheet that provides each travel agency with the information needed to define the goals that they would like to achieve and to plan their overall 
strategy. Players are asked to examine (abstract experimentation) the market characteristics what they need and what they will offer in an auction. They are instructed to offer rooms to be auctioned, and they will be bidding against other players to purchase the rooms they need. Each agency is presented with a supply/demand sheet. Appendix 1 illustrates supply/demand sheets of twelve agencies.

Table 3. Master Auction Matrix

\begin{tabular}{|l|c|c|c|}
\hline Item & $\begin{array}{c}\text { Quantity } \\
\text { Supplied }\end{array}$ & $\begin{array}{c}\text { Quantity } \\
\text { Demanded }\end{array}$ & $\begin{array}{c}\text { Market } \\
\text { Status }\end{array}$ \\
\hline Ramada & 200 & 600 & Shortage \\
\hline $\begin{array}{l}\text { Fairfield } \\
\text { Inn }\end{array}$ & 600 & 1,000 & Shortage \\
\hline $\begin{array}{l}\text { Holiday } \\
\text { Inn } \\
\text { Express }\end{array}$ & 200 & 2,000 & Shortage \\
\hline $\begin{array}{l}\text { Holiday } \\
\text { Inn } \\
\text { Hotels }\end{array}$ & 1,200 & 1,600 & Shortage \\
\hline $\begin{array}{l}\text { Inter- } \\
\text { Conti- } \\
\text { nental }\end{array}$ & 1,000 & 1,000 & Even \\
\hline $\begin{array}{l}\text { Radisson } \\
\text { Hotels }\end{array}$ & 800 & 800 & Even \\
\hline $\begin{array}{l}\text { Trave- } \\
\text { lodge }\end{array}$ & 20,000 & 20,000 & Even \\
\hline $\begin{array}{l}\text { Crowne } \\
\text { Plaza }\end{array}$ & 1,600 & 1,600 & Even \\
\hline $\begin{array}{l}\text { La } \\
\text { Quinta }\end{array}$ & 18,000 & 4,000 & Surplus \\
\hline Days Inn & 1,600 & 1,000 & Surplus \\
\hline $\begin{array}{l}\text { Best Inn } \\
\text { \& Suites }\end{array}$ & 800 & 400 & Surplus \\
\hline $\begin{array}{l}\text { Four } \\
\text { Season } \\
\text { Hotel }\end{array}$ & 12,000 & 10,000 & Surplus \\
\hline
\end{tabular}

For large classes, those sheets can be multiplied to meet size class demands. It is only necessary to create names for the new agencies if the full set is replicated since there will be no change to the supply/demand structure of the market. If a different number of agencies are created, it will be necessary to review the Master Auction Matrix to determine whether there has been a change to market structure and change the quantities to maintain the balance between the different market conditions. If the focus is on the auction rather than market structure, no changes would need to be made in the quantities supplied and demanded.

Players have rooms to trade (representing quantity supplied) and rooms needed (representing quantity demanded). For example, AAA Travel will bring the following items to be auctioned: 40 rooms in Ramada Hotel, 60 rooms in Holiday-Inn Express, 120 rooms in Radisson Hotels, 240 rooms in Crowne Plaza, 240 rooms in Days Inn Hotel, and 120 rooms in Best Inn \& Suites Hotel. The AAA agent will bid for 150 rooms in Fairfield Inn, 400 rooms in Holiday Inn Hotels, 150 rooms in Inter-Continental Hotel, 3,000 rooms in Travelodge Hotel, 400 rooms in La Quinta Hotel, and 1,500 rooms in Four Seasons Hotel.

A short period is allowed to answer general questions and to review the instructions before auction begins. Once each team has time to look over the list of items to be auctioned and needed, the auction session begins. Each team needs to determine the value of each item, and to make the auction trades necessary to acquire the needed goods.

Each player is given a budget that must be used to complete trading. For example, players can have a budget of $\$ 250,000$. If a player purchases $\$ 250,000$ worth of hotel rooms, he/she runs out of money and must stop bidding. The minimum bid can be set at $\$ 50$ or $\$ 100$ per set of rooms supplied from a particular hotel to prevent excessive profiteering. However, the prices established by the bidding can change the players' established plans, and the players will have to adjust rapidly. Though the simulation may at first seem complex, the experience process can flow quite smoothly and with little aggravation if number of students is very large.

The instructor acts as the auctioneer. Each team in turn offers a "lot" of rooms for sale from a single hotel chain, like "50 rooms from Days Inn". Note that the size of the lot does not need to represent the entire inventory. Small lots can be offered at first to identify which are more valuable than others to determine the market conditions. If the lots offered are too small, there will not be enough time to complete the auction, but there should still be time enough for the students to experience the auction process. Teams in need of the offered rooms bid on them until the top price is established. When the auctioneer says "Sold" both the selling and buying teams adjust their cash balance and room inventory. The auctioneer must move quickly to the next offer in order to allow sufficient time for each agency to make several offers.

The bidding can proceed quickly, and this adds another dimension to the problem for the individual teams. The designated bidder must receive instructions from the rest of the team concerning how much money can be spent. There will also be the need for the team to pay attention to the market to determine which and how many rooms to offer for sale. If the auctioneer can keep a quick pace, teams will have to solve the problem of internal communications. If a team is not ready with an offer when called upon, the auctioneer skips over them and moves to the next team. Losing a turn can have severe repercussions since the team would lose a source of income. 


\subsection{Determine if there will be Individual Players or Teams}

The number of players dictates the complexity of the game. The optimal number of players is twelve students. Fewer players result in a simplified structure that prohibits some of the more interesting interactions during the game. More than twelve players create a situation where the market becomes more dynamic, but it is possible for the players to grasp what is going on in the auction market. Large classes can be broken up into teams, with each team developing its own strategy and dividing responsibilities among group members. There should only be one designated bidder on each team. Someone should take responsibility for accounting and management of the group.

\section{Concrete Experience, Reflective Observation, and Active Experimentation}

\subsection{General Rules of the Game}

Basic skills and jargon are reviewed before the auction market is opened. If students are unfamiliar with the activities involved, time should be devoted to brief explanation. The goal is to allow players to undergo a concrete experience through discovery. If the participants seem confused about all the complexities of the activity, they can be given some reassurances with time for an active experimentation followed by reflective observation. A large amount of time should not be spent to make all the directions and behaviors clear. The best way to learn and understand an educational exercise such as an auction game is to play it and work out problems as they arise during concrete experience.

Players with some previous experience will find the simulation enhances their reflection on accounting and marketing skills as well as their strategic management abilities as the players make decisions while actively participating in the auction. Reflective observation allows students to broaden their understanding of various market situations and how market structures can affect students' behavior. For participants with little or no playing experience, the simulation provides practical management, marketing, and strategic decision-making skills in a realistic format.

Teams are given times for reflective observation at the end of the auction session. Once they go through abstract conceptualization, concrete experience, reflective observation, and active experimentation, they must report their cash balance and what rooms they have in inventory, including rooms successfully traded and rooms not traded. They will be able to state that the success or failure of each team is determined in two ways. First, players could be identified as winners or losers by determining whether or not they were able to meet their individual needs. Players collecting all the needed items, and maybe some extras, win over players who cannot meet their basic needs. A second measure of individual success considers the cash position of each player. Players who end up with more cash have performed better than their competitors. The "winner" would be the team with the most cash. A third measure of the success or failure could be defined as a combination of the ability of all players to meet their individual needs and amass cash; this measure offers the broadest measure of success.

\subsection{The Experiential Learning Environment}

The bidding can be carried out during one class period. The length of the auction should be about 45-50 minutes, or until everyone has met their needs.

Table 4. Auction Bid Sheet

\begin{tabular}{|l|l|}
\hline \multicolumn{1}{|c|}{ Round \#1: } & \multicolumn{1}{c|}{ Round \#4: } \\
AAA Travel & AAA Travel \\
Sunset Travel Agency & Sunset Travel Agency \\
Travel-with-Us & Travel-with-Us \\
Los Angeles Travel Agency & Los Angeles Travel Agency \\
Continental Tours & Continental Tours \\
Western Travel Agency & Western Travel Agency \\
Midwest Travel & Midwest Travel \\
Pilgrim Tours & Pilgrim Tours \\
Orlando Paradise & Orlando Paradise \\
Las Vegas Tours & Las Vegas Tours \\
Rivera Travel & Rivera Travel \\
Pacific Tours & Pacific Tours \\
\hline \multicolumn{1}{|c|}{ Round \#2: } & Round \#5: \\
AAA Travel & AAA Travel \\
Sunset Travel Agency & Sunset Travel Agency \\
Travel-with-Us & Travel-with-Us \\
Los Angeles Travel Agency & Los Angeles Travel Agency \\
Continental Tours & Continental Tours \\
Western Travel Agency & Western Travel Agency \\
Midwest Travel & Midwest Travel \\
Pilgrim Tours & Pilgrim Tours \\
Orlando Paradise & Orlando Paradise \\
Las Vegas Tours & Las Vegas Tours \\
Rivera Travel & Rivera Travel \\
Pacific Tours & Pacific Tours \\
\hline \multicolumn{1}{|c|}{ Round \#3: } & Round \#6: \\
AAA Travel & AAA Travel \\
Sunset Travel Agency & Sunset Travel Agency \\
Travel-with-Us & Travel-with-Us \\
Los Angeles Travel Agency & Los Angeles Travel Agency \\
Continental Tours & Continental Tours \\
Western Travel Agency & Western Travel Agency \\
Midwest Travel & Midwest Travel \\
Pilgrim Tours & Pilgrim Tours \\
Orlando Paradise & Orlando Paradise \\
Las Vegas Tours & Rivera Travel \\
Rivera Travel & Pacific Tours
\end{tabular}

The bid sheet (see Table 4) illustrates six cycles where the auctioneer calls agencies to auction their rooms in the same order. For example, AAA Travel 
Office is the first agency, while Pacific Tours is the last agency to bring rooms to auction during each round of an auction. The rotation of the agencies could be rotated or randomized to create additional complexity.

The auctioneer has the option to record the name of the buyer and the amount paid for each lot of rooms and the number of rooms auctioned. This information can be used to audit the players to make sure that no one overspent the allotted budget or "created" additional rooms to be sold.

The bidding should be repeated as necessary, at least six times, to assure enough rooms from each hotel are available in the market. It is the responsibility of the instructor to conduct the auction at a brisk pace. While it is expected that the first bids will be slow due to players becoming accustomed to the pattern of the auction, it is necessary to complete a bid on an average of every 20-30 seconds. This might sound fast, but once the auction begins it is possible to achieve this rate without difficulty. The speed at which the auction runs is one of the more important factors in the game.

\subsection{The Roles for the Players}

All travel agencies start the auction game with different product mix but the same potential for success. Each travel agency must make strategic decisions every bidding period concerning their selling, buying, budgeting, and accounting. This decision-making cycle will continue over several periods of the auction until the auctioneer (the instructor) stops the game and evaluates each tourist agency's operations. It is explained to the students that the goal of the game is for each travel agency to maximize its individual wealth.

The winner of the game is the team that receives all the needed rooms and the highest cash balance. Since the goal is wealth maximization, each travel agency is to try to get as many "rooms" as possible. All rooms brought into the market should be traded away for profit and to purchase other rooms that are demanded. The students are not informed of the underlying market conditions or the structure of a surplus or shortage rooms in particular hotel. Any such information could influence the participants' actions and adversely affect the simulation's educational value.

\subsection{Transactions and Rules}

Students do not know the optimum strategy at the begging of the auction, since the players' interactions in the auction will establish their playing strategies. This dynamic aspect requires players to modify their strategies to meet evolving auction conditions. Students' strategies and plans are not to be submitted to the instructor prior to the auction, since the auctioning strategies change several times over the during the auction period.

It is irrelevant for the success of the game to indicate the hotel's location, type, and numbers of nights to be sold. This information would make the game more complex without adding any educational content value. However, the complexity of the simulation provides a basis for the players to make challenging and efficient strategic decision-making.

\subsection{An Overall Evaluation Method}

A debriefing session is held to review lessons learned from the game. Debriefing might indicate (1) the basic characteristics of an auction market, (2) multiple aspects of complexity of markets, (3) how the dynamic nature of the auction market causes players to affect, and possibly change, their initial strategic plans, (4) how the auction game helps students learn to acquire information through listening and observation, and allows them to practice information organization and evaluation skills, and (5) how the auction market functions and the role of the auction market in the tourism and hospitality industry.

Each group can be asked to review its initial plan and identify any changes that may have been made to that plan. Students should be expected to provide answers to the following questions: Did you get everything you needed?; How did you get everything you needed?; What was the main obstacle in obtaining all you needed?; What strategy or strategies did you take?; Did you observe any differences in results obtained when you changed your strategies?; Based on the experience you gained did you develop a different strategy?; How did you gather information you obtained?; What information was needed to accomplish your task successfully?; Did you observe any market clearing processes?; Did you observe any market dynamics taking place while completing your tasks?

To provide answers to those questions, students can work within their groups. Some other topics could be raised. Which topics are raised should be based on the instructor's observation of the simulation? If some students have never experienced an auction, some time can be used to examine the nature of an auction market environment. The follow-up discussion should demonstrate how well students understand the structures and forces of the auction. The debriefing session might focus on students' strategies and the results of their strategies and a discussion about how the players gathered and processed information during the auction. The players can also be expected to recognize the need for accurate accounting, the value and the role of market information, and information control techniques. 
It is recommended that auction be repeated twice until players develop the ability to adapt rapidly to changing market structures. Once the players have become accustomed to the interaction, team decision making, and the auction experience, it is easy to introduce changes to the market structure that illustrate different aspects of market's behavior and information processing. After the game is completed and the lessons are learned the instructor can write a teaching timeline. Table 5 provides a Teaching Timeline for the Auction Game.

\section{Table 5. Timeline of the Action Game}

1. Divide class into teams. There should be twelve
teams with 2-3 members each.
2. Have teams sit together in specified locations.
3. Distribute a trading sheet to each team. Table 2
presents all twelve individual trading sheets.
4. Ask each team to determine and assign the
various roles of the team members and the
strategy the team will use in the auction.
5. Instruct teams to prepare the accounting system
and the forms to keep track of their sales and
purchases and the amounts paid for those
auctioning transactions.
Identify the bidder for each team.
Begin the auction. Use the Bid Sheet (Table 3)
to establish the sequence for auctioning
goods and to record the price and quantity
supplied of each item. The auction should
last about $45-50$ minutes, with at least 5-6
repetitions of the Bid Sheet.
7.
Determine each team's room inventories and the
cash balances.
Conduct a debriefing session to discuss items
like market behavior, market strategy, price
discovery, and budget control. Discuss the
usability of the accounting forms each team
had prepared. Discussion can be provided
prior to the auction if students have no
accounting background. The debriefing
session can also be used to focus on those
aspects of the auction market that the
instructor wishes to highlight.

The instructor should provide handouts to each student prior to the experiment. The handout should include the basic description of the game, the rules, and the roles of the. Too much information will limit the effectiveness of learning where discovery, exploration, and reflection are required for learning and the development of life-long learning skill such as critical thinking.

\section{Reflective Experimentation - Lessons Learned and the Debriefing Session}

Several lessons can be learned after replaying the simulation. For example, students may learn that there are interesting possibilities for collusion. A bidder may decide to help a rival bidder by not continuing to bid up the price in the expectation that the other bidder will reciprocate by not bidding up the price on some other item to be sold later. Students may also find that bidders have more difficulty in carrying out their schemes if bidding is conducted by collusion. In many cases, they may be able to cheat on their supposed conspirators by secretly undercutting their bids. By observing this behavior, students see the role and value of ethics in markets.

The auctioneer must work to create an atmosphere of excitement and competition among the bidders. Sometimes bidders seem to become too excited in their bidding and bid more than they had initially planned. Sometimes bidders think that they can scare off the competition by increasing the bid suddenly by a large amount. A bidder may make a bid dramatically larger than previous bids hoping that other bidders do not have time to reconsider their valuations before the rooms are sold. Students learn that these things happen in real auctions because information is available to everyone. While participating in an auction, students learn that people are not entirely confident of their own judgment of the object's value that is for sale. Seeing that someone else is eager to buy may make a bidder raise his own estimate of the value's object.

The most important part of any game is reviewing the lessons learned from the game. This is where the participants' experiences are transformed into education. Merely "playing a game" in a classroom is not sufficient, and there must be a review that reinforces the game's goals. This is also the most difficult aspect of any game, since it is quite possible that things occurred during the game were not anticipated. The instructor must be aware of everything that is happening during the game, even the unplanned events, and be able to translate all the activity into an appropriate set of lessons learned.

The debriefing session is characterized by student participation. This review is the actual goal of any game, getting students involved in and responsible for their own education. In the past, when the instructor asked properly chosen questions, students raised their hands and wanted to tell of their experiences and observations. Students were able to identify the major characteristics of the auction market and the problems that existed within the market. Students often presented observations concerning the market or the processes within the non-auction market that were not anticipated by the instructor. Such situations are why the instructor needs to have a wide enough background and a deep enough understanding of the simulation's structure to identify how these observations fit into the simulation.

Students frame concepts with familiar examples during the debriefing session. Basic concepts that they are supposed to practice and learn become more 
meaningful when the students are able to link them with their own experiences. Practice and experience help students reinforce material learned. As students undertake active, effective, and systematic information gathering, theories no longer become abstract concepts that are merely memorized.

The review of the trading session and the lessons learned should touch on accounting and information processing. Market behavior, strategies, and ethics may also be appropriate discussion topics. The success of the individual teams should open the discussion about how the team gathered and processed information. At this point the discussion can turn to the roles of each member within the team.

The use of a central bookkeeper who maintains the records while other team members are involved in bidding and whether individual team member should specialize in given commodities or be allowed to auction the entire portfolio of assets are worthwhile topics for this discussion. All participants should be drawn into discussion. It is necessary that all players recognize their roles in the market. This opportunity to relate the world of the simulation to the real world is the payoff of the entire exercise. The shared experience of the exercise forms a touchstone that can be used in other class sessions to illustrate other lessons and give them a personal context for the student.

\section{Conclusions}

The paper provides information on how to design an auction game for experiential learning in the context of Kolb's model and how to tailor it for tourism and hospitality classroom learning. The audience of this paper will fall somewhere between those who are motivated to use games for learning for the first time and those who have been using them for a long time but want to expose their students to an auction.

Activities based on concrete experience, reflective observation, abstract conceptualization, and active experimentation exercises can be used to improve teaching effectiveness through promotion of active learning, and effective information gathering and can be followed by comprehension, application, analysis, synthesis, and evaluation. All these elements contribute to a process of learning where cognitive thinking skills are developed and practiced. Simulations and games give students real experiences and make the concepts learned more meaningful. They can be used in large classrooms where students can play individually or be placed in groups where each player accepts a designated role.

The debriefing sessions that follow the exercises stimulate discussion and provide a background for the analysis of real-life situations. Simulations and games have a strong impact on students because role-playing facilitates active learning, permits the acceptance of new concepts, and generates increased student interest, enthusiasm, and motivation. Students' comments show that simulations and games work because the exercises can be structured and allow students to become an important element of the learning process.

The Auction Game shows how games and simulations game be used and modified to accommodate both small and large classes. The effectiveness of students' learning is not compromised because in a large class. Faculty members who use games and simulations in a large classroom can deliberately structure the experience so that each player is fully engaged in the learning process.

Active and experiential learning is based on the deliberate set-up of the exercises to accommodate large-size classrooms. Putting students in groups in a large classroom is a quick solution to the problem, but specific tasks must be developed by the instructor to make sure that all students are active. The Auction Game is structured so that there are many different roles that student can play, and so every student can be active. This idea of broadbased activity is crucial to using any game or simulation in a large class setting.

\section{References}

[1] Wurdinger, S., and J. Carlson. (2010). Teaching for experiential learning: Five approaches that work. Lanham, MD: Rowman \& Littlefield Education.

[2] Kolb, A. and D. Kolb (2009). On Becoming a Learner: The Concept of Learning Identity. In Bamford-Rees et. al. (Eds.), Learning Never Ends: Essays on Adult Learning Inspired by the Life and Work of David O. Justice. Chicago, IL: CAEL Forum and News.

[3] Kolb, A. Y. and D.A. Kolb. (2008). Experiential Learning Theory: A Dynamic, Holistic Approach to Management Learning, Education and Development (4268). In Armstrong Handbook of Management Learning, Education and Development; The Sage Publication.

[4] Zapalska, A. and D. Brozik. (2001). Learning Market Skills through Simulation. Journal of Private Enterprise, Spring,pp. 56-70.

[5] Cooper, L., Orrell J., and M. Bowden. (2010). Work Integrated Learning: A guide to effective practice. New York, NY: Routledge.

[6] Brozik, D. and A. Zapalska. (2000). The Restaurant Game. Simulation and Gaming. September, pp. 407-416.

[7] Dewey, J. (1916). Democracy and Education. New York: MacMillan.

[8] Wolfe, D.E. and E.T. Byrne. (1975). Research on Experiential Learning: Enhancing the Process, Simulation 
Games and Experiential Learning in Action. Richards H. Buskirk (ed), pp. 325-336.

[10] Kolb, D. (1984). Experiential Learning: Experience as the Source of Learning and Development. Englewood Cliffs, NJ: Prentice Hall.

[11] Fry, H., Ketteridge, S., and S. Marshall. (Eds). (2009). A handbook for teaching and learning in higher education: Enhancing academic practice (3rd ed.). New York, USA: Routledge.

[12] Cohen, L., Manion, L. and Morrison, K., (2008). A Guide to Teaching Practice, 5th ed., Routledge, Abingdon.

[13] Johnson, D. and Johnson, R., (2008). Social Interdependence Theory and Cooperative Learning: The Teacher's Role. In R. M. Gillies, A. Ashman \& J. Terwel (Eds.), Teacher's Role in Implementing Cooperative Learning in the Classroom (pp. 9-37). New York, U.S.A: Springer.

[14] Becker, E. and M. Watts. (1995). Teaching Tools: Teaching Methods in Undergraduate Economics. Economic Inquiry. 33, pp. 692-700.

[15] Baker, A., Jensen, P. and D.A. Kolb. (2002). Conversational Learning: An Experiential Approach to knowledge Creation. Westport, CT Quorum Books.

[16] Wells, D. (1991). Laboratory Experiments for Undergraduate Instruction in Economics. Journal of Economic Education. 22 (Summer): pp. 293-300.

[17] Moon J. (2004). A Handbook of Reflective and Experiential Learning: Theory and Practice. New York: Routledge.

[18] Broadbent, J., Panadero, E., and D. Boud. (2018). Implementing Summative Assessment with a Formative Flavour: A Case Study in a Large Class, Assessment \& Evaluation in Higher Education, 43(2), pp. 307-322.

[19] Lund D. K., and S. Wright. (2017). Embedding Engaged Learning in High Enrollment Lecture-Based Classes, Higher Education: The International Journal of Higher Education Research, 74(4), pp. 651-668.

[20] McLeod, S.A. (2010). Kolb Learning Styles: http://www.simplypsychology.org/learning-kolb.html.

[21] Bergsteiner, H., and Avery, G.C., (2014). The twincycle experiential learning model: Reconceptualizing Kolb's theory, Studies in Continuing Education, https://www.tandfonline.com/loi/csce20 
Appendix 1. All Individual Trading Sheets

\begin{tabular}{|c|c|c|c|}
\hline \multicolumn{4}{|c|}{ AAA Travel } \\
\hline \multicolumn{2}{|c|}{ Rooms Available } & \multicolumn{2}{|c|}{ Rooms Needed } \\
\hline Ramada & 40 & Fairfield Inn & 150 \\
\hline $\begin{array}{l}\text { Holiday Inn } \\
\text { Express }\end{array}$ & 60 & $\begin{array}{l}\text { Holiday Inn } \\
\text { Hotels }\end{array}$ & 400 \\
\hline $\begin{array}{l}\text { Radisson } \\
\text { Hotels }\end{array}$ & 120 & $\begin{array}{l}\text { Inter- } \\
\text { Continental }\end{array}$ & 150 \\
\hline Crowne Plaza & 240 & Travelodge & 3,000 \\
\hline Days Inn & 240 & La Quinta & 400 \\
\hline $\begin{array}{l}\text { Best Inn \& } \\
\text { Suites }\end{array}$ & 120 & $\begin{array}{l}\text { Four Seasons } \\
\text { Hotel }\end{array}$ & 1,500 \\
\hline
\end{tabular}

\begin{tabular}{|c|c|c|c|}
\hline \multicolumn{4}{|c|}{ Sunset Travel Agency } \\
\hline \multicolumn{2}{|c|}{ Rooms Available } & \multicolumn{2}{|c|}{ Rooms Needed } \\
\hline Ramada & 30 & Fairfield Inn & 150 \\
\hline $\begin{array}{ll}\text { Holiday } & \text { Inn } \\
\text { Hotels } & \\
\end{array}$ & 120 & $\begin{array}{ll}\text { Holiday } & \text { Inn } \\
\text { Express } & \\
\end{array}$ & 200 \\
\hline $\begin{array}{l}\text { Inter- } \\
\text { Continental }\end{array}$ & 250 & $\begin{array}{l}\text { Radisson } \\
\text { Hotels }\end{array}$ & 160 \\
\hline Crowne Plaza & 240 & Travelodge & 3,000 \\
\hline Days Inn & 240 & La Quinta & 400 \\
\hline $\begin{array}{l}\text { Four Seasons } \\
\text { Hotel }\end{array}$ & 3,000 & $\begin{array}{l}\text { Best Inn \& } \\
\text { Suites }\end{array}$ & 60 \\
\hline
\end{tabular}

\begin{tabular}{|c|c|c|c|}
\hline \multicolumn{4}{|c|}{ Travel-with-Us } \\
\hline \multicolumn{2}{|c|}{ Rooms Available } & \multicolumn{2}{|c|}{ Rooms Needed } \\
\hline Ramada & 40 & Fairfield Inn & 150 \\
\hline $\begin{array}{l}\text { Holiday Inn } \\
\text { Express }\end{array}$ & 60 & $\begin{array}{l}\text { Holiday Inn } \\
\text { Hotels }\end{array}$ & 400 \\
\hline Radisson Hotels & 120 & $\begin{array}{l}\text { Inter- } \\
\text { Continental }\end{array}$ & 150 \\
\hline Travelodge & 240 & Crowne Plaza & 3,000 \\
\hline La Quinta & 240 & Days Inn & 400 \\
\hline $\begin{array}{l}\text { Four Seasons } \\
\text { Hotel }\end{array}$ & 120 & $\begin{array}{l}\text { Best Inn \& } \\
\text { Suites }\end{array}$ & 1,500 \\
\hline
\end{tabular}

\begin{tabular}{|c|c|c|c|}
\hline \multicolumn{4}{|c|}{ Los Angeles Travel Agency } \\
\hline \multicolumn{2}{|c|}{ Rooms Available } & \multicolumn{2}{|c|}{ Rooms Needed } \\
\hline Fairfield Inn & 30 & Ramada & 90 \\
\hline $\begin{array}{l}\text { Holiday } \text { Inn } \\
\text { Hotels }\end{array}$ & 120 & $\begin{array}{ll}\text { Holiday } & \text { Inn } \\
\text { Express } & \end{array}$ & 200 \\
\hline $\begin{array}{l}\text { Inter- } \\
\text { Continental }\end{array}$ & 250 & $\begin{array}{l}\text { Radisson } \\
\text { Hotels }\end{array}$ & 120 \\
\hline Crowne Plaza & 240 & Travelodge & 2,000 \\
\hline La Quinta & 240 & Days Inn & 300 \\
\hline $\begin{array}{l}\text { Best Inn \& } \\
\text { Suites }\end{array}$ & 3,000 & $\begin{array}{l}\text { Four Seasons } \\
\text { Hotel }\end{array}$ & 1,500 \\
\hline
\end{tabular}

\begin{tabular}{|c|c|c|c|}
\hline \multicolumn{4}{|c|}{ Continental Tours } \\
\hline \multicolumn{2}{|c|}{ Rooms Available } & \multicolumn{2}{|c|}{ Rooms Needed } \\
\hline Fairfield Inn & 90 & Ramada & 90 \\
\hline $\begin{array}{ll}\text { Holiday } & \text { Inn } \\
\text { Hotels } & \\
\end{array}$ & 180 & $\begin{array}{ll}\text { Holiday } & \text { Inn } \\
\text { Express } & \end{array}$ & 300 \\
\hline $\begin{array}{l}\text { Radisson } \\
\text { Hotels }\end{array}$ & 160 & $\begin{array}{l}\text { Inter- } \\
\text { Continental }\end{array}$ & 250 \\
\hline Travelodge & 5,000 & Crowne Plaza & 480 \\
\hline Days Inn & 160 & La Quinta & 300 \\
\hline $\begin{array}{l}\text { Best Inn \& } \\
\text { Suites }\end{array}$ & 120 & $\begin{array}{l}\text { Four Seasons } \\
\text { Hotel }\end{array}$ & 2,000 \\
\hline
\end{tabular}

\begin{tabular}{|c|c|c|c|}
\hline \multicolumn{4}{|c|}{ Western Travel Agency } \\
\hline \multicolumn{2}{|c|}{ Rooms Available } & \multicolumn{2}{|c|}{ Rooms Needed } \\
\hline Fairfield Inn & 90 & Ramada & 120 \\
\hline $\begin{array}{l}\text { Holiday Inn } \\
\text { Hotels }\end{array}$ & 180 & $\begin{array}{l}\text { Holiday Inn } \\
\text { Express }\end{array}$ & 300 \\
\hline $\begin{array}{l}\text { Inter- } \\
\text { Continental }\end{array}$ & 100 & $\begin{array}{l}\text { Radisson } \\
\text { Hotels }\end{array}$ & 120 \\
\hline Crowne Plaza & 160 & Travelodge & 2,000 \\
\hline Days Inn & 160 & La Quinta & 600 \\
\hline $\begin{array}{l}\text { Four Seasons } \\
\text { Hotel }\end{array}$ & 1,200 & $\begin{array}{l}\text { Best Inn \& } \\
\text { Suites }\end{array}$ & 60 \\
\hline
\end{tabular}

\begin{tabular}{|l|r|}
\hline \multicolumn{2}{|c|}{ Midwest } \\
\hline \multicolumn{2}{|c|}{ Rooms Available } \\
\hline Ramada & 40 \\
\hline $\begin{array}{l}\text { Holiday Inn } \\
\text { Express }\end{array}$ & 60 \\
\hline $\begin{array}{l}\text { Radisson } \\
\text { Hotels }\end{array}$ & 120 \\
\hline Crowne Plaza & 240 \\
\hline Days Inn & 240
\end{tabular}

\begin{tabular}{|c|c|}
\hline \multicolumn{2}{|c|}{ Rooms Needed } \\
\hline Fairfield Inn & 150 \\
\hline $\begin{array}{l}\text { Holiday Inn } \\
\text { Hotels }\end{array}$ & 400 \\
\hline $\begin{array}{l}\text { Inter- } \\
\text { Continental }\end{array}$ & 150 \\
\hline Travelodge & 3,000 \\
\hline La Quinta & 400 \\
\hline
\end{tabular}

\begin{tabular}{|l|r|l|l|r|}
\hline \multicolumn{4}{|c|}{ Pilgrim Tours } \\
\hline \multicolumn{2}{|c|}{ Rooms Available } & & \multicolumn{2}{c|}{ Rooms Needed } \\
\cline { 1 - 1 } Ramada & 30 & Fairfield Inn & 150 \\
\cline { 1 - 1 } $\begin{array}{l}\text { Holiday Inn } \\
\text { Hotels }\end{array}$ & 120 & $\begin{array}{l}\text { Holiday Inn } \\
\text { Express }\end{array}$ & 200 \\
\cline { 1 - 1 } $\begin{array}{l}\text { Inter- } \\
\text { Continental }\end{array}$ & 250 & $\begin{array}{l}\text { Radisson } \\
\text { Hotels }\end{array}$ & 160 \\
${$\cline { 1 - 1 }$} }$ & 240 & Travelodge & 3,000 \\
\hline Days Inn & 240 & & La Quinta & 400
\end{tabular}




\begin{tabular}{|l|l|l|l|l|}
\hline $\begin{array}{l}\text { Best Inn \& } \\
\text { Suites }\end{array}$ & 120 & $\begin{array}{l}\text { Four Seasons } \\
\text { Hotel }\end{array}$ & 1,500 \\
\hline
\end{tabular}

\begin{tabular}{|l|l|l|l|l|}
\cline { 1 - 1 } & $\begin{array}{l}\text { Four Seasons } \\
\text { Hotel }\end{array}$ & 3,000 & $\begin{array}{l}\text { Best Inn \& } \\
\text { Suites }\end{array}$ & 60 \\
\hline
\end{tabular}

\begin{tabular}{|c|c|c|c|}
\hline \multicolumn{4}{|c|}{ Orlando Paradise } \\
\hline \multicolumn{2}{|c|}{ Rooms Available } & \multicolumn{2}{|c|}{ Rooms Needed } \\
\hline Ramada & 30 & Fairfield Inn & 200 \\
\hline $\begin{array}{l}\text { Holiday Inn } \\
\text { Express }\end{array}$ & 40 & $\begin{array}{l}\text { Holiday Inn } \\
\text { Hotels }\end{array}$ & 400 \\
\hline $\begin{array}{l}\text { Radisson } \\
\text { Hotels }\end{array}$ & 120 & $\begin{array}{l}\text { Inter- } \\
\text { Continental }\end{array}$ & 100 \\
\hline Travelodge & 5,000 & Crowne Plaza & 320 \\
\hline La Quinta & 4,500 & Days Inn & 200 \\
\hline $\begin{array}{ll}\text { Four Seasons } \\
\text { Hotel }\end{array}$ & 1,800 & $\begin{array}{l}\text { Best Inn \& } \\
\text { Suites }\end{array}$ & 80 \\
\hline
\end{tabular}

\begin{tabular}{|c|c|c|c|}
\hline \multicolumn{4}{|c|}{ Las Vegas Tours } \\
\hline \multicolumn{2}{|c|}{ Rooms Available } & \multicolumn{2}{|c|}{ Rooms Needed } \\
\hline Fairfield Inn & 120 & Ramada & 90 \\
\hline $\begin{array}{l}\text { Holiday Inn } \\
\text { Hotels }\end{array}$ & 120 & $\begin{array}{l}\text { Holiday Inn } \\
\text { Express }\end{array}$ & 200 \\
\hline $\begin{array}{l}\text { Inter- } \\
\text { Continental }\end{array}$ & 15 & $\begin{array}{l}\text { Radisson } \\
\text { Hotels }\end{array}$ & 120 \\
\hline Crowne Plaza & 160 & Travelodge & 2.000 \\
\hline La Quinta & 4,500 & Days Inn & 300 \\
\hline $\begin{array}{l}\text { Best Inn \& } \\
\text { Suites }\end{array}$ & 160 & $\begin{array}{l}\text { Four Seasons } \\
\text { Hotel }\end{array}$ & 1,500 \\
\hline
\end{tabular}

\begin{tabular}{|c|c|c|c|}
\hline \multicolumn{4}{|c|}{ Riviera Travel } \\
\hline \multicolumn{2}{|c|}{ Rooms Available } & \multicolumn{2}{|c|}{ Rooms Needed } \\
\hline Fairfield Inn & 90 & Ramada & 90 \\
\hline $\begin{array}{l}\text { Holiday Inn } \\
\text { Hotels }\end{array}$ & 180 & $\begin{array}{l}\text { Holiday } \text { Inn } \\
\text { Express }\end{array}$ & 300 \\
\hline $\begin{array}{l}\text { Radisson } \\
\text { Hotels }\end{array}$ & 160 & $\begin{array}{l}\text { Inter- } \\
\text { Continental }\end{array}$ & 250 \\
\hline Travelodge & 5,000 & Crowne Plaza & 480 \\
\hline Days Inn & 160 & La Quinta & 600 \\
\hline $\begin{array}{l}\text { Best Inn \& } \\
\text { Suites }\end{array}$ & 120 & $\begin{array}{l}\text { Four Seasons } \\
\text { Hotel }\end{array}$ & 2,000 \\
\hline
\end{tabular}

\begin{tabular}{|c|c|c|c|}
\hline \multicolumn{4}{|c|}{ Pacific Tours } \\
\hline \multicolumn{2}{|c|}{ Rooms Available } & \multicolumn{2}{|c|}{ Rooms Needed } \\
\hline $\begin{array}{l}\text { Fairfield } \\
\text { Inn }\end{array}$ & 90 & Ramada & 120 \\
\hline $\begin{array}{l}\text { Holiday Inn } \\
\text { Hotels }\end{array}$ & 180 & $\begin{array}{l}\text { Holiday Inn } \\
\text { Express }\end{array}$ & 300 \\
\hline $\begin{array}{l}\text { Inter- } \\
\text { Continental }\end{array}$ & 100 & $\begin{array}{l}\text { Radisson } \\
\text { Hotels }\end{array}$ & 120 \\
\hline $\begin{array}{l}\text { Crowne } \\
\text { Plaza }\end{array}$ & 160 & Travelodge & 2,000 \\
\hline Days Inn & 160 & La Quinta & 600 \\
\hline $\begin{array}{l}\text { Four } \\
\text { Seasons } \\
\text { Hotel }\end{array}$ & 1,200 & $\begin{array}{l}\text { Best Inn \& } \\
\text { Suites }\end{array}$ & 60 \\
\hline
\end{tabular}

